\title{
A new species of Choleoeimeria (Apicomplexa: Eimeriidae) from the lizard, Scincus hemprichii (Sauria: Scincidae)
}

\author{
Abdel-Azeem S. Abdel-Baki ${ }^{1,2}$, Saleh Al-Quraishy ${ }^{1}$ and Heba M. Abdel-Haleem² \\ ${ }^{1}$ Zoology Department, College of Science, King Saud University, Riyadh, Saudi Arabia; \\ ${ }^{2}$ Zoology Department, Faculty of Science, Beni-Suef University, Egypt
}

\begin{abstract}
Four out of twenty (20\%) specimens of the lizard Scincus hemprichii Wiegmann, collected in Saudi Arabia were infected with a previously undescribed species of Choleoeimeria. Oocysts of Choleoeimeria jazanensis sp. $\mathrm{n}$. are cylindroidal, $26 \times 15 \mu \mathrm{m}$, with a smooth bilayered wall and a shape index of 1.7. Oocyst residuum and micropyle are absent. Sporocysts are subspherical, $10 \times 7 \mu \mathrm{m}$, with a shape index of 1.3 . The Stieda body is absent. Sporozoites are banana-shaped, $10 \times 3 \mu \mathrm{m}$, with one refractile body and enclosed the fine granulated sporocyst residuum. The endogenous development is confined to the gall bladder epithelium, with infected cells being displaced from the epithelium layer towards lumen. Mature meronts are subspherical and estimates to produce 9-12 merozoites. Microgamonts are spherical in shape with diameter of $13 \mu \mathrm{m}$. Macrogamonts are subspherical with a prominent nucleus in centre and wall-forming bodies at periphery.
\end{abstract}

Keywords: Coccidia, taxonomy, oocysts, endogenous stages, gall bladder, Reptalia, Saudi Arabia

The generic classification of eimeriid coccidia of reptilian hosts has been a matter of longstanding scholarly discussion because most taxonomic studies have been limited to inadequate species descriptions based solely on the morphology of exogenous stages (oocysts). There is also a lack of information on the life-cycles and biology of most species (Jirků et al. 2009).

The genus Choleoeimeria Paperna et Landsberg, 1989 was proposed to accommodate Eimeria species of reptilian hosts. The genus exhibits a number of unique features, specifically elongated to ellipsoidal oocysts (L/W ratio 1.6-2.2) with sporulation in the lumen of the gall bladder and digestive tract of the host animal, a lack of the Stieda body and a propensity to undergo endogenous development in the cells of the bile epithelium (Paperna and Landsberg 1989). The sporocyst wall of species of this genus is composed of two plates joined by a meridional suture (Sloboda and Modrý 2006).

Phylogenetic analysis, based on nucleotide sequence of small sub-unit ribosomal RNA gene, confirmed separate status of the genus Choleoeimeria - Jirků et al. 2002. They argued, based both on their sequence data and the unique morphological characters mentioned above, that Choleoeimeria should be considered a distinct genus. This has led some authors, e.g. Lainson and Paperna (1999), Abdel-Baki et al. (2008, 2009), McAllister (2012) to take the position that it is not possible to be sure of the generic status of eimeriid coccidians from reptiles without reference to the endogenous stages. From this perspective, we provide here a description of a new species of Choleoeimeria from the gall bladder of the lizard, Scincus hemprichii Wiegmann, in Saudi Arabia.

\section{MATERIALS AND METHODS}

Twenty specimens of Scincus hemprichii were captured by hand in Jazan Province $\left(16^{\circ} 53^{\prime} \mathrm{N} ; 42^{\circ} 32^{\prime} \mathrm{E}\right)$ in the western region of Saudi Arabia in June 2012 and transported to the King Saud University. They were kept alive in separate plastic cages in order to collect faeces. The presence of oocysts was determined by direct examination of suspensions prepared from faeces macerated with water. Lizards found to be heavily infected were killed and gall bladder infection was confirmed by direct examination of the bile fluid. Oocysts were measured and photographed according to the guidelines of Duszynski and Wilber (1997).

To determine the site of infection, selected tissues (stomach, intestine, gall bladder, liver, kidney) were fixed in $10 \%$ buffered formalin. Fixed tissues were processed for histology using standard methods; paraffin sections were stained with haematoxylin and eosin (H\&E). The measurements of the oocysts and endogenous stages are given in micrometres as arithmetic mean \pm standard deviation (range), together with the shape index (ratio of length/width).

\section{RESULTS}

Choleoeimeria jazanensis sp. $\mathrm{n}$.

Figs. 1-8

\section{Exogenous stages (oocysts)}

Sporulated oocysts tetrasporocystic, cylindrical, $26 \pm$ $0.4(25-27) \times 15 \pm 0.3(14-16)$, with a length to width ra- 

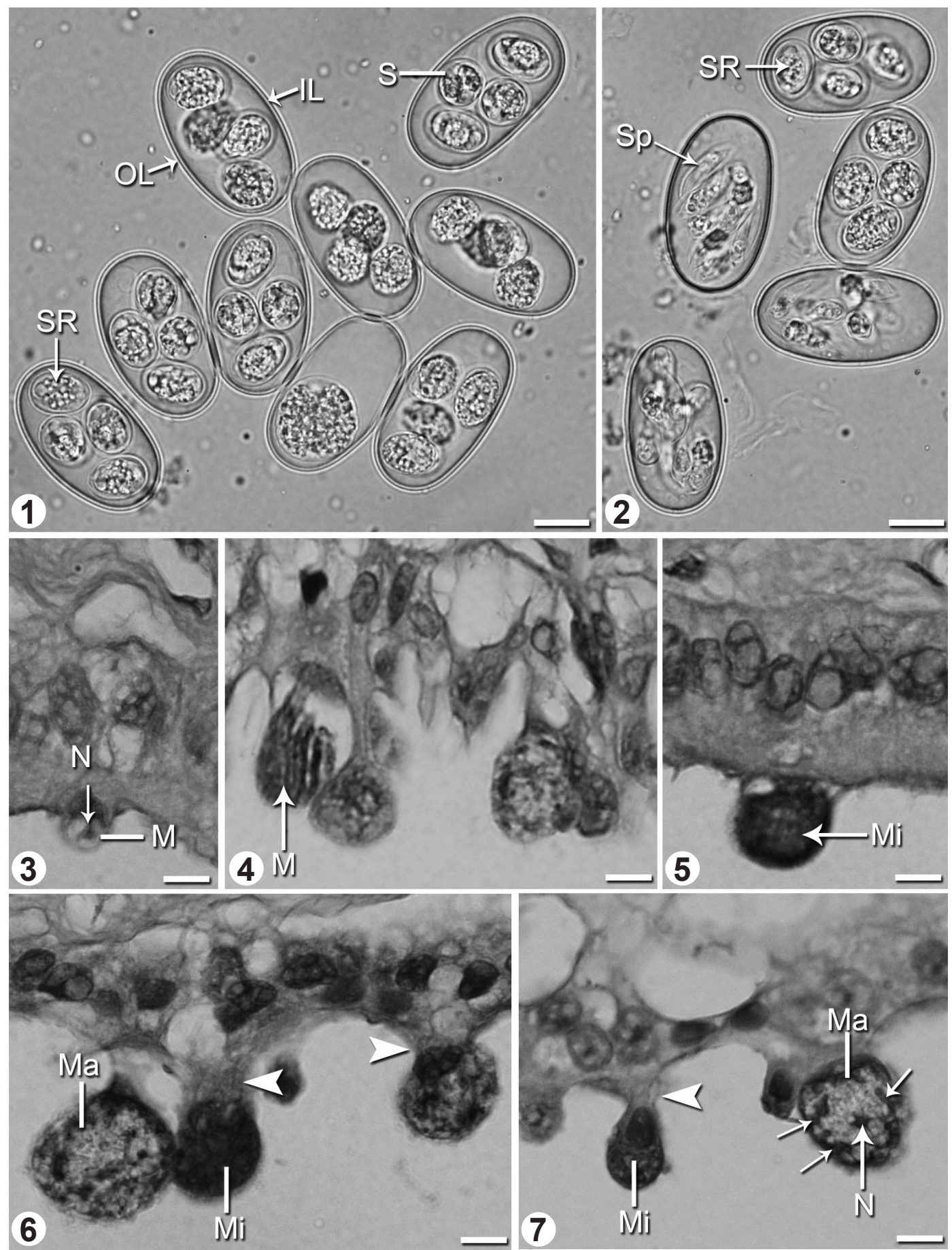

Figs. 1-7. Coleoeimeria jazanensis sp. n. from the gall bladder of Sicncus hemprichii. Figs. 1, 2. Oocysts at different stages of maturation from the gallbladder of the lizard Scincus hemprichii. The oocyst surrounded with outer layer (OL) and inner layer (IL) membrane, containing four sporocysts (S) with sporocyst residuum (SR) and two sporozoites (Sp). Scale-bar = 10 $\mu \mathrm{m}$. Figs. 3-7. Endogenous development and endogenous stages. The infected epithelia become hypertrophied and displaced to the lumen of the gallbladder and contact with the basal membrane by a thin pedicle (arrowheads). Scale-bar $=10 \mu \mathrm{m}$. Fig. 3. Uninucleated meront (M) and with a nucleus (N). Fig. 4. Mature meronts (M). Fig. 5-7. Microgamonts (Mi) and macrogamonts (Ma) with wall-forming bodies arranged at the periphery (arrows) and a centrally located nucleus $(\mathrm{N})$.

tio (L/W) of 1.7 (1.6-1.8) (Figs. 1, 2, 8). Oocyst residuum, micropyle and polar granule absent. Oocyst wall colourless, bilayered, smooth, 1 thick, inner wall slightly thicker than outer wall (Fig. 1). Sporocysts subspherical, $11 \pm 0.3$ $(10-12) \times 7 \pm 0.2(6-8)$ with a length to width ratio of 1.3 (1.2-1.4), with a smooth, colourless and uni-layered 
sporocyst wall (Fig. 1). Stieda body or other localized thickening of wall absent. Sporozoites banana-shaped (Fig. 2), measure $10 \times 4$, curved around a residuum composed of finely dispersed granules (Figs. 1, 2). With age, sporocysts frequently dehisce and leave sporozoites free in oocyst (Fig. 2).

\section{Endogenous stages}

Merogony and gametogony stages developed in epithelial cells of the gall bladder as well as along biliary duct (Figs. 3-7). No infection observed in other examined organs. Infected epithelial cells become hypertrophied, displaced to lumen of gall bladder, usually in contact with basal membrane by a thin pedicle (Figs. 6, 7). Youngest observed meronts uninucleated, nearly spherical and measured 5 (4-6) in diameter (Fig. 3). Mature meronts subspherical, measuring $12(11-14) \times 7(6-8)$, produce 9-12 merozoites (Fig. 4). Microgamonts mostly spherical in shape (Figs. 5-7), approximately $13(12-15)$ in diameter. Macrogamonts mostly subspherical (Figs. 6, 7) with a prominent nucleus in centre and wall-forming bodies at periphery (Fig. 7), measuring 15 (14-16) in diameter.

Type host: Scincus hemprichii Wiegmann (Sauria: Scincidae).

Type 1 oc ality: Jazan Province $\left(16^{\circ} 53^{\prime} \mathrm{N} ; 42^{\circ} 32^{\prime} \mathrm{E}\right)$, western region of Saudi Arabia.

Prevalence: $20 \%(4 / 20)$.

Site of infection: Gall bladder.

Sporulation: Endogenous; both sporulated and unsporulated oocysts were found in the gall bladder lumen and intestinal contents prior to being voided in the faeces.

Type material: Photosyntype of sporulated oocysts and one slide syntypes of H\&E-stained endogenous stages in the gall bladder epithelia deposited in the parasitological collection of the Hungarian Natural History Museum under the inventory number HNHM-70391.

Etymology: The specific epithet is derived from the host locality, Jazan Province.

Remarks. So far, 21 Choleoeimeria species have been described from lizards of the family Scincidae. Choleoeimeria jazanensis sp. n. (Table 1) most closely resembles the following six species: C. scinci Phisalix, 1923, C. auratae Alyousif et Al-Rasheid, 2001, C. hemprichii Alyousif et Al-Shawa, 2005, C. saqanqouri Abdel-Baki, El-Fayomi, Sakran et Abdel-Haleem, 2008, C. riyadhae Alyousif et Al-Shawa, 2010 and C. mitranusensis AlQuraishy, 2011. Oocysts of C. jazanensis sp. n. can be easily distinguished from $C$. hemprichii, the only other Choleoeimeria species previously described from the same host (Scincus hemprichii), as they are considerably shorter and thinner, and have a cylindrical shape compared to ellipsoid one of C. hemprichii. Moreover, C. hemprichii has a compact and membrane banded sporocyst residuum $v s$ a dispersed one in the present species. Each of the other Choleoeimeria species described from

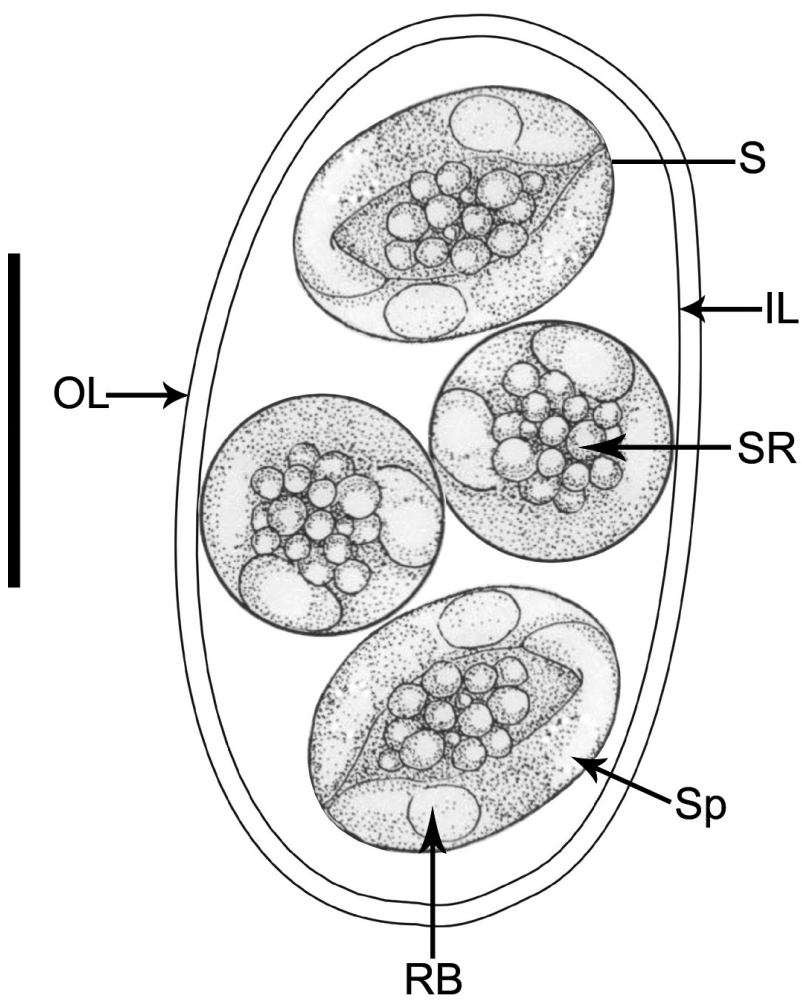

Fig. 8. Schematic drawing of an oocyst of Choleoeimeria jazanensis sp. n. The oocyst surrounded with outer layer (OL) and inner layer (IL) membrane and containing four sporocysts (S), each one with sporocyst residuum (SR) and two sporozoites $(\mathrm{Sp})$; each sporozoite have one refractile bodies (RB). Scale bar $=10 \mu \mathrm{m}$.

hosts of the family Scincidae (C. auratae, C. mitranusensis, $C$. riyadhae, $C$. saqanqouri and $C$. scinci) have much longer and wider oocysts than those of $C$. jazanensis.

\section{DISCUSSION}

Following Levine (1988), the description of eimeriid coccidia from reptiles have tended to be based solely on the morphology of their mature oocysts and sporocysts, with no consideration for any differences that might exist in the rest of the parasites' life-cycle stages (Lainson 2003, Abdel-Baki et al. 2009). The risks of identifying some eimerian coccidians solely by the morphology of their oocysts and sporocysts have been discussed by numerous authors (see Finkelman and Paperna 1994) and it is impossible to be sure of the generic status of eimeriid coccidia from reptiles without reference to the endogenous stages or using molecular data (Lainson and Paperna 1999, Abdel-Baki et al. 2008, 2009, McAllister 2012).

Paperna and Landsberg (1989) proposed the genus Choleoeimeria to comprise some Eimeria and Eimeria-like coccidians infecting the biliary epithelium of reptiles. Species of the genus Choleoeimeria have elliptical oocysts (L/W ratio 1.6-2.2) with endogenous development confined to the gall bladder epithelia and lack 
Table 1. Comparative descriptive measurements ( $\mu \mathrm{m})$ of Choleoeimeria jazanensis sp. n. (in bold) and morphologically similar species from lizards of the family Scincidae.

\begin{tabular}{|c|c|c|c|c|c|c|}
\hline Species & Host & Oocyst size & Oocyst shape * & Sporocyst size & $\begin{array}{l}\text { Sporocyst } \\
\text { shape [SI] }\end{array}$ & References \\
\hline Choleoeimeria scinci & Scincus scincus & 25-36 long & Cylindrical (?) & $14 \times 10$ & $? / ?$ & Modrý and Jirků 2006 \\
\hline Choleoeimeria auratae & Mabouya aurata & $\begin{array}{l}27.5(22-31.5) \\
\times 18.5(13.5-21.5)\end{array}$ & Cylindrical (1.5) & $\begin{array}{l}12(10.5-13) \\
\times 8.5(7.5-9)\end{array}$ & $\begin{array}{l}\text { Ellipsoidal } \\
(?)\end{array}$ & Modrý and Jirků 2006 \\
\hline Choleoeimeria hemprichii & Scincus hemprichii & $\begin{array}{l}34.5(32.5-36.3) \\
\times 21.5(20.7-22.5)\end{array}$ & $\begin{array}{l}\text { Ellipsoidal } \\
(1.62)\end{array}$ & $\begin{array}{l}11.5(11-12.5) \\
\times 8.0(7.5-8.5)\end{array}$ & $\begin{array}{l}\text { Ellipsoidal } \\
(1.43)\end{array}$ & Modrý and Jirků 2006 \\
\hline Choleoeimeria saqanqouri & Scincus scincus & $\begin{array}{l}35(33.5-37) \\
\times 23.5(22-25)\end{array}$ & $\begin{array}{l}\text { Ellipsoidal } \\
1.5(1.4-1.6)\end{array}$ & $\begin{array}{l}11.5(10.5-12) \\
\times 9(7.5-10)\end{array}$ & $\begin{array}{l}\text { Ellipsoidal } \\
1.3(1.1-1.6)\end{array}$ & Abdel-Baki et al. 2008 \\
\hline Choleoeimeria riyadhae & Scincus scincus & $\begin{array}{l}37(33.5-39) \\
\times 30.5(29-32.5)\end{array}$ & $\begin{array}{l}\text { Ellipsoidal } \\
1.21(1.19-1.23)\end{array}$ & $\begin{array}{l}15(14-15.5) \\
\times 9(8-10.5)\end{array}$ & $\begin{array}{l}\text { Ellipsoidal } \\
1.63(1.52-1.74)\end{array}$ & $\begin{array}{l}\text { Alyousif and } \\
\text { Al-Shawa } 2010\end{array}$ \\
\hline Choleoeimeria mitranusensis & Scincus mitranus & $\begin{array}{l}29(28-31) \\
\times 20(19-21)\end{array}$ & $\begin{array}{l}\text { Ellipsoidal } \\
1.4(1.3-1.5)\end{array}$ & $\begin{array}{l}11(9-12) \\
\times 8(7-9)\end{array}$ & $\begin{array}{l}\text { Ellipsoidal } \\
1.3(1.2-1.5)\end{array}$ & Al-Quraishy 2011 \\
\hline \multicolumn{3}{|c|}{$\begin{array}{r}\text { Choleoeimeria jazanensis sp. n. Scincus hemprichii } 26(25-27) \\
\times 15(14-16)\end{array}$} & $\begin{array}{l}\text { Cylindrical } \\
1.7(1.6-1.8)\end{array}$ & $\begin{array}{l}10(9-11) \\
\times 7(6-8)\end{array}$ & $\begin{array}{l}\text { Subspherical } \\
1.3(1.2-1.4)\end{array}$ & the present study \\
\hline
\end{tabular}

? No data; * length/width ratio expressed as mean with range in parentheses.

a Stieda body. However, some authors have not adopted this classification and have instead tentatively placed all tetrasporocystic species, including eimeriid coccidians of reptile hosts, into the collective genus Eimeria Schneider, 1875 - e.g. Daszak and Ball (1991), Upton et al. (1991), Telford (1997), Asmundsson et al. (2001), Alyousif and Al-Rasheid (2001), Daszak et al. (2009). The status of the genus Choleoeimeria as a sister clade to the Eimeriidae was confirmed by Jirků et al. (2002). Modrý and Jirků (2006) and Sloboda and Modrý (2006) revised Eimerialike species from the Scincidae and Chamaeleonidae. They stressed the necessity of studying the endogenous stages of eimeriid coccidians to allocate them to correct genus and species.

In the present study, we demonstrated that the gall bladder was the only site for the endogenous development of newly described species and no endogenous stages were detected in the intestine. Therefore, we follow Paperna and Landsberg (1989) and assigned the biliary coccidium recorded in this study as a member of Choleoeimeria.

Acknowledgments. The authors extend their appreciation to the Deanship of Scientific Research at King Saud University for funding the work through the research group project number RGP-VPP-004.

\section{REFERENCES}

Abdel-Baki A.S., El-Fayomi H.M., Sakran Th., Abdel-HalEEM H.M. 2008. Choleoeimeria saqanqouri sp. nov. (Apicomplexa: Eimeriidae) infecting the gallbladder of Scincus scincus scincus (Reptilia: Scincidae) from Egypt. Acta Protozool. 47: 143-147.

Abdel-Baki A.S., El-Fayomi H.M., Sakran Th., Abdel-HalEEM H.M. 2009: Endogenous stages of Choleoeimeria baltrocki (Daszak et Ball, 1991) n. comb. infecting the gallbladder of gold skink, Eumeces schneiderii Daudin, 1802 from Egypt. Acta Parasitol. 54: 85-89.

Al-Quraishy S. 2011: A new Choleoeimeria species (Apicomplexa: Eimeriidae) infecting the gallbladder of Scincus mitranus (Reptilia: Scincidae) in Saudi Arabia. J. Parasitol. 97: $1125-1128$.

Alyousif M.S., Al-Rasheid K.A.S. 2001: Eimeria auratae n. sp. (Apicomplexa: Eimeriidae) infecting the lizard Mabuya aurata in Saudi Arabia. Parasitol. Int. 50: 27-32.

Alyousif M.S., Al-Shawa Y. 2005: Eimeria hemprichii n. sp. (Apicomplexa: Eimeriidae) from the lizard Scincus hemprichii (Sauria: Scincidae) in Saudi Arabia. J. Egypt. Soc. Parasitol. 35: 723-729.

Alyousif M.S., Al-Shawa Y. 2010: Choleoeimeria riyadhae sp. n. (Apicomplexa: Eimeriidae) from the lizard, Scincus scincus (Sauria: Scincidae) in Saudi Arabia. J. Egypt. Soc. Parasitol. 40: 159-164.
Asmundsson I.M., Upton S.J., Freed R.S. 2001: Five new species of coccidia (Apicomplexa: Eimeriidae) from colubrid snakes of Ecuador. J. Parasitol. 87: 1077-1081.

DASZAK P., BALl S.J. 1991. Five new species of Eimeria (Apicomplexa: Eimeriidae) from lizards. Syst. Parasitol. 20: 141-147.

Daszak P., Ball S. J., Jones C.G., Streicker D.G., Snow K.R. 2009: Six new species of coccidia (Apicomplexa: Eimeriidae) from endangered Phelsuma spp. geckoes (Sauria: Gekkonidae) of the Black River Gorges National Park, Mauritius. Folia Parasitol. 56: 233-241.

Duszynski D.W., Wilber P.G. 1997: Guidelines for publishing new species descriptions of eimerians (Apicomplexa: Eimeriidae). J. Parasitol. 83: 333

Finkelman S., Paperna I. 1994: The endogenous development of two new species of Isospora from skinks. Syst. Parasitol. 27: 227-235.

JiRKU゚ M., JiRKŮ M., OBorník M., LukeŠ J., ModRÝ D. 2009: A model for taxonomic work on homoxenous coccidia: redescription, host specificity, and molecular phylogeny of Eimeria ranae Dobell, 1909, with a review of anuran-host Eimeria (Apicomplexa: Eimeriorina). J. Euk. Microbiol. 56: 39-51.

Jirkủ M., Modrý D., Š́lapeta J.R., Koudela B., Lukeš J. 2002: The phylogeny of Goussia and Choleoeimeria (Apicomplexa: Eimeriorina) and the evolution of excystation structures in coccidian. Protist 135: 379-390. 
LAINSON R. 2003: Some coccidial parasites of the lizard Amphisbaena alba (Reptilia: Amphisbaenia: Amphisbaenidae). Mem. Inst. Oswaldo Cruz 98: 927-936.

Lainson R., Paperna I. 1999: Some coccidia from the gallbladder and intestine of the teiid lizard Ameiva ameiva ameiva and the gecko Hemidactylus mabouia in North Brazil. Parasite 6: $151-162$.

Levine N.D. 1988: The Protozoan Phylum Apicomplexa. Vol. I. CRC Press, Boca Raton, Florida, 203 pp.

McAllister C.T. 2012: A new species of Choleoeimeria (Apicomplexa: Eimeriidae) from Oustalet's chameleon, Furcifer oustaleti (Sauria: Chamaeleonidae). Folia Parasitol. 59: 12-14.

ModRÝ D., JIRKUீ M. 2006: Three new species of coccidia (Apicomplexa: Eimeriorina) from the marble-throated skink, Marmorosphax tricolor Bavay, 1869 (Reptilia: Scincidae), endemic to New Caledonia with a taxonomic revision of Eimeria spp. from scincid hosts. Parasitol. Res. 99: 419-428.

Received 14 December 2012
Paperna I., Landsberg J.H. 1989: Description and taxonomic discussion of eimerian coccidians from African and Levantine geckoes. S. Afr. J. Zool. 24: 345-355.

Sloboda M., Modrý D. 2006: New species of Choleoeimeria (Apicomplexa: Eimeriidae) from the veiled chameleon, Chamaeleo calyptratus (Sauria: Chamaeleonidae), with taxonomic revision of eimerian coccidia from chameleons. Folia Parasitol. 53: 91-97.

Telford S.R. 1997: Two new species of Eimeria Schneider, 1875 (Apicomplexa: Eimeriidae) from skinks in Florida. Syst. Parasitol. 36: 27-30.

Upton S.J., McAllister C.T., Trauth S.E. 1991: Two new species of coccidia (Apicomplexa: Eimeriidae) from Eumeces fasciatus (Sauria: Scincidae) in Arkansas. Can. J. Zool. 69: 2028-2030.

Accepted 23 February 2013 